\title{
Studies on the metabolism of neutral steroids by preimplantation rabbit blastocysts in vitro and the origin of blastocyst oestrogen*
}

\author{
M. M. Singh $\dagger$ and W. D. Booth \\ A.R.C. Institute of Animal Physiology, Animal Research Station, \\ 307 Huntingdon Road, Cambridge, U.K.
}

\begin{abstract}
Summary. Day-6 rabbit blastocysts were incubated with ${ }^{3} \mathrm{H}$-labelled neutral steroids. Pregnenolone metabolism was insignificant, but progesterone was extensively metabolized to $5 \beta$-pregnanedione ( $5 \beta$-pregnane-3,20-dione) and $5 \beta$-pregnanolone ( $5 \beta$ -

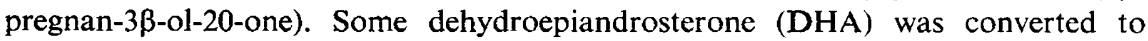
5 -androstene-3 $\beta, 17 \beta$-diol; androstenedione and testosterone were interconverted, and both 4 -ene steroids were metabolized to $5 \alpha$-reduced compounds. There was no evidence for oestrogen synthesis from progesterone or androgens. Exogenous cofactors had no significant effect on the course of steroid metabolism. Oestradiol and oestrone were determined in blastocysts, and high levels of oestrogen were found in blastocysts from superovulating rabbits. Injection of $\left[{ }^{3} \mathrm{H}\right]$ oestradiol into pregnant rabbits gave rise to radioactivity associated primarily with oestradiol in uterine tissue, uterine flushings and blastocysts.

It is concluded (1) that the capacity of the Day- 6 rabbit blastocyst to metabolize progesterone and androgen may be utilized in vivo to protect the blastocyst from excess maternal progesterone, and to involve androgens in an anabolic role, and (2) that blastocyst oestrogen may be partly of maternal origin.
\end{abstract}

\section{Introduction}

Preimplantation blastocysts and uterine fluid of rabbits contain significant amounts of progesterone (Seamark \& Lutwak-Mann, 1972; Fuchs \& Beling, 1974; Cowan, Manes \& Hagerman, 1976; Borland, Erickson \& Ducibella, 1977; Fowler, Johnson, Walters \& Eager, 1977) and oestrogen (Dickmann, Dey \& Sen Gupta, 1975; Borland et al., 1977). It is generally accepted that progesterone in the uterine ffushings and blastocyst of the rabbit is maternal in origin, but there is considerable speculation about the origin of the oestrogen. Dickmann et al. (1975) have suggested, on the basis of histochemical work, that rabbit embryos synthesize the oestrogen that is required for early embryonic development involving morula to blastocyst transformation, loss of the zona pellucida, and the induction of implantation.

An early study by Huff \& Eik-Nes (1966) showed that rabbit blastocysts have the ability to metabolize neutral steroids in vitro, but oestrogens were not identified as one of the products. The preimplantation blastocyst of the pig, like that of the rabbit, also contains progesterone and oestradiol. Furthermore the pig blastocyst can convert dehydroepiandrosterone and androstenedione to oestrogen in vitro (Perry, Heap \& Amoroso, 1973). Gadsby, Burton, Heap \& Perry (1976) have also demonstrated that the pig blastocyst can convert pregnenolone or progesterone to oestrogen only when exogenous cofactors are added to the incubation medium.

The aim of the present work was to acquire more information on the origin of oestrogen in the preimplantation rabbit blastocyst.

* Reprint requests to Dr W. D. Booth.

$\dagger$ Present address: Endocrinology Division, Central Drug Research Institute, Lucknow, India. 


\section{Materials and Methods}

Adult female rabbits were mated to males of proven fertility, and immediately after mating (Day 0) were injected intravenously with 25 i.u. hCG (Paines \& Byrne Ltd, Greenford, Middlesex, U.K.). Other females were induced to superovulate by the injection of 100 i.u. PMSG (Paines \& Byrne Ltd) 4 days before mating and of 50 i.u. hCG immediately after mating.

The does were killed with $1.5 \mathrm{ml}(200 \mathrm{mg} / \mathrm{ml})$ sodium pentobarbitone (Expiral: Abbott Laboratories Ltd, Queensborough, Kent, U.K.) given intravenously either on the morning of Day 5 or Day 6 post coitum. The uterine horns were excised, and each horn was opened to expose the blastocysts which were removed, washed several times with sterile incubation medium, and then incubated with radioactively labelled steroids.

[7 (n)- $\left.{ }^{3} \mathrm{H}\right]$ Pregnenolone (sp. act. $\left.10 \cdot 5 \mathrm{Ci} / \mathrm{mmol}\right),\left[1,2,6,7(\mathrm{n})-{ }^{3} \mathrm{H}\right]$ progesterone (sp. act $81 \mathrm{Ci} /$ $\mathrm{mmol}$ ), $\left[7 \alpha_{-}{ }^{3} \mathrm{H}\right]$ dehydroepiandrosterone (sp. act. $0 \cdot 5 \mathrm{Ci} / \mathrm{mmol}$ ), $\left[7 \alpha^{-3} \mathrm{H}\right]$ androstenedione (sp. act. $8.3 \mathrm{Ci} / \mathrm{mmol}$ ), and $\left[1 \alpha, 2 \alpha-{ }^{3} \mathrm{H}\right]$ testosterone (sp. act. $58 \mathrm{Ci} / \mathrm{mmol}$ ) were purchased from the Radiochemical Centre, Amersham, Bucks, U.K., and their radiochemical purity was checked by thin-layer chromatography before use. Unlabelled steroids were purchased from Sigma (London) Chemical Company Ltd (Poole, Dorset, U.K.) for use as carrier steroids and for recrystallization purposes. All organic solvents were glass-distilled before use.

\section{Incubation medium}

Medium 199 with Earle's salts (Flow Laboratories Ltd, Irvine, Ayrshire, U.K.) was supplemented with sodium bicarbonate $(2.2 \mathrm{~g} / \mathrm{l})$, sodium pyruvate $(0.03 \mathrm{~g} / \mathrm{l})$, bovine serum albumin $(1 \mathrm{~g} / \mathrm{l})$, penicillin $(0.06 \mathrm{~g} / \mathrm{l})$ and streptomycin $(0.05 \mathrm{~g} / \mathrm{l})$ and used for the incubation of blastocysts with radioactively labelled steroids (see above). The medium was passed through a sterile millipore filter (pore size $0.45 \mu \mathrm{m}$ ) just before use, and the $\mathrm{pH}$ was adjusted to approximately 7.4 with $5 \% \mathrm{CO}_{2}$ in air.

\section{Steroid metabolism in blastocysts}

In pilot experiments, incubations were carried out with blastocysts in the presence of ${ }^{3} \mathrm{H}$-labelled steroid substrates, and metabolites were tentatively identified so that in subsequent incubations appropriate carrier steroids could be added. The final incubations were carried out, in duplicate, with each ${ }^{3} \mathrm{H}$-labelled steroid as substrate for 1 , or 5 or more blastocysts. Approximately $1 \mu \mathrm{Ci}$ of each steroid in benzene:ethanol $(1: 1 \mathrm{v} / \mathrm{v})$ was added to each sterilized incubation tube (Flow Laboratories Ltd), and the solvent removed under a stream of nitrogen at $45^{\circ} \mathrm{C}$. Sterile incubation medium ( $\left.3 \mathrm{ml}\right)$ was added to each tube, which was then gassed with $5 \% \mathrm{CO}_{2}$ in air before adding the required number of blastocysts; two tubes without blastocysts served as controls. All tubes were stoppered and incubated at $37^{\circ} \mathrm{C}$ for $24 \mathrm{~h}$; and the $\mathrm{pH}$ was adjusted as necessary with further $5 \% \mathrm{CO}_{2}$ in air. Simultaneous incubations were also carried out in the presence of added cofactors NAD and NADPH (each $0.6 \mathrm{mg} / 3 \mathrm{ml}$ ) obtained from Boehringer Corporation (London) Ltd, Lewes, Sussex, U.K.

After incubation for $24 \mathrm{~h}$, the blastocysts were ruptured and the contents of each tube were extracted with diethyl ether ( $5 \mathrm{ml}$, twice). Subsequent isolation and identification of radiometabolites were carried out, as described by Booth (1977), with the Bush A paper chromatography system to separate mono- and di-hydroxy metabolites of progesterone, and thin-layer chromatography (two runs with toluene:ethyl acetate $(9: 1 \mathrm{v} / \mathrm{v})$, one run with benzene:ether $(9: 1 \mathrm{v} / \mathrm{v})($ Gower, 1964)) for non-polar steroids to separate $5 \alpha$-from $5 \beta$-pregnanedione.

\section{Oestrogen in blastocysts}

In a preliminary study, 52 Day- 6 blastocysts (Group 1) were collected and stored at $-80^{\circ} \mathrm{C}$. Additional blastocysts (Group 2, 430; Group 3, 137) were collected on Day 6 from the superovulating rabbits by the procedure described previously (Group 2), or by flushing the uteri (Group 3,10 ml/horn) with sterile phosphate-buffered saline, $\mathrm{pH} 7 \cdot 3$ (Dulbecco 'A', Oxoid Ltd, U.K.). Contamination of 
the flushings with blood was avoided as far as possible. The blastocysts were washed several times with buffered-saline and stored at $-80^{\circ} \mathrm{C}$. The uterine flushings were immediately centrifuged $(900 \mathrm{~g})$ at room temperature, pooled (18 animals) and freeze-dried to reduce the volume to about $30 \mathrm{ml}$.

The blastocysts were extracted with diethyl ether as described previously, and the concentrated pooled uterine flushings were extracted with $150 \mathrm{ml}$ diethyl ether. Radioimmunoassay of oestrogen in the blastocysts and uterine flushings was carried out after the initial ether extracts had been processed as follows. The blastocyst extract (Group 1) was dissolved in ethanol (1 ml). This extract was then divided into two $0.5 \mathrm{ml}$ samples without any further purification for the radioimmunoassay of total unconjugated oestrogen as described by Newcomb, Booth \& Rowson (1977). Half of the blastocyst extracts of Groups 2 and 3, and the uterine flushings extract (Group 3) were subjected to thin-layer chromatography with benzene: ethyl acetate $(3: 1 \mathrm{v} / \mathrm{v})$ as the eluent after the plates $(10 \times$ $20 \mathrm{~cm}$, silica gel $250 \mu \mathrm{m}$ : Anachem Uniplate, supplied by Hawfell, Cambridge, U.K.) had been washed three times in ethyl acetate. Areas $(2 \times 3 \mathrm{~cm})$ on the plate corresponding to oestradiol and oestrone and the remaining areas between the origin and solvent front were removed by vacuum into Pasteur pipettes fitted with a glass-wool plug, and the steroids were eluted into glass tubes with $2 \mathrm{ml}$ chloroform: acetone $(1: 1, \mathrm{v} / \mathrm{v})$. The solvent was removed under a current of air at $45^{\circ} \mathrm{C}$, and each extract was then dissolved in ethanol $(100 \mu \mathrm{l}) ; 50 \mu \mathrm{l}$ (or less for the most quantitative work) of each extract were used for radioimmunoassay as described above, with the addition of a standard curve for oestrone which cross-reacted $55 \%$ with the antiserum to oestradiol. Androgens and progestagens had no significant cross-reaction with the antiserum. Details of the precision and sensitivity of the radioimmunoassay as applied to cow blood plasma are described by Booth, Newcomb, Strange, Rowson \& Sacher (1975). No significant deviations from these parameters were found when the assay was applied to rabbit blastocysts and uterine flushings. The assays were carried out in duplicate and the minimum amount of oestrogen determined $(28 \mathrm{pg})$ was readily distinguishable from the blank $(<5 \mathrm{pg})$. The use of thin-layer chromatography also gave extra specificity to the method.

\section{Transfer of ${ }^{3} \mathrm{H}$-labelled oestradiol to blastocysts}

Radioactively labelled oestradiol $(50 \mu \mathrm{Ci})\left[6,7(\mathrm{n})-{ }^{3} \mathrm{H}\right]$ oestradiol- $17 \beta$ (sp. act. $41 \mathrm{Ci} / \mathrm{mmol}$ : Radiochemical Centre) in $1 \mathrm{ml} 0.9 \% \mathrm{NaCl}$ in glass-distilled water:ethanol $(9: 1 \mathrm{v} / \mathrm{v})$ was injected into the marginal ear vein of 6 rabbits (Day 5 or Day $6 p . c$.) and one oestrous rabbit, and the animals were killed at various times after the injection (see Table 4). At autopsy, blastocysts, uterine flushings and uteri were collected as described above together with some peripheral blood. The total blastocysts, uterine flushings and blood plasma $(1 \mathrm{ml})$ of each animal were extracted with diethyl ether ( 5 vols), and the total uterine tissue was combined and homogenized in water $(100 \mathrm{ml})$ before extraction with 5 volumes of diethyl ether. Similarly, samples of endometrium ( $<10 \mathrm{mg}$ each) from two rabbits (Nos 5/4 and 6/4), were homogenized in water before extraction with 5 volumes of diethyl ether. Gross lipid was removed from the uterine extract by partitioning it between $20 \mathrm{ml}$ light petroleum ether (b.p. $40-60^{\circ} \mathrm{C}$ ) and $83 \%$ aqueous methanol $(6 \times 20 \mathrm{ml})$. Unlabelled oestradiol and oestrone $(20 \mu \mathrm{g}$ each) were added to each of the diethyl ether extracts, and the $83 \%$ aqueous methanol extract (the petroleum ether phase was discarded), before evaporation to dryness by rotary vacuum evaporation. The residues corresponding to the blastocysts, uterine flushings and total uterine tissue were subjected to thin-layer chromatography with benzene:acetone $(4: 1 \mathrm{v} / \mathrm{v})$, and the distribution of radioactivity on the chromatograms was located with a scanner as previously described (Booth, 1977); areas corresponding to oestradiol and oestrone were eluted for liquid scintillation counting.

\section{Results}

\section{Steroid metabolism in blastocysts}

The various metabolites formed during incubation of rabbit blastocysts with ${ }^{3} \mathrm{H}$-labelled steroid substrates are shown in Tables 1 and 2, and recrystallization data for some of these metabolites are shown in Table 3. 
Table 1. Metabolism ( $\%$ conversion to metabolites $/ 24 \mathrm{~h}$ ) of ${ }^{3} \mathrm{H}$-labelled progesterone by rabbit blastocysts (Day 6 p.c.) in vitro

\begin{tabular}{cccccccc}
\hline & \multicolumn{3}{c}{ Metabolites } & & & & \\
$\begin{array}{c}\text { No. of } \\
\text { blastocysts }\end{array}$ & $\begin{array}{c}5 \beta \text {-Pregnane- } \\
\text { dione }\end{array}$ & $\begin{array}{c}5 \beta \text {-Pregnano- } \\
\text { lone }\end{array}$ & $\begin{array}{c}\text { Unidentified } \\
\text { metabolite }\end{array}$ & Androgens & Oestrogens & $\begin{array}{c}\text { Total } \\
\text { metabolism } \\
(\%)\end{array}$ \\
\hline 1 & $32 \cdot 1$ & $14 \cdot 0$ & $7 \cdot 94$ & ND & ND & $54 \cdot 0$ \\
5 & $35 \cdot 6$ & $22 \cdot 3$ & $34 \cdot 2$ & ND & ND & $92 \cdot 1$ \\
\hline
\end{tabular}

Values are the mean of two incubations. ND, none detected; $5 \beta$-pregnanedione $=5 \beta$-pregnane-3,20-dione; $5 \beta$-pregnanolone $=5 \beta$-pregnan-3 $\alpha$-ol-20-one.

Table 2. Metabolism (\% conversion to metabolites $/ 24 \mathrm{~h}$ ) of ${ }^{3} \mathrm{H}$-labelled $\mathrm{C}_{19}$ steroids by rabbit blastocysts (Day 6 p.c.) in vitro

\begin{tabular}{|c|c|c|c|c|c|c|c|c|c|c|}
\hline \multirow{2}{*}{$\begin{array}{l}\text { No. of } \\
\text { blasto- } \\
\text { cysts }\end{array}$} & \multirow[b]{2}{*}{$\begin{array}{l}\text { Sub- } \\
\text { strate }\end{array}$} & \multicolumn{8}{|c|}{ Metabolites } & \multirow{2}{*}{$\begin{array}{c}\text { Total } \\
\text { meta- } \\
\text { bolism } \\
(\%)\end{array}$} \\
\hline & & ${ }^{5} \mathrm{~A}$ & Ad & $\begin{array}{c}\mathrm{Te}+ \\
\text { EpiTe* }\end{array}$ & $\begin{array}{c}5 \alpha- \\
\text { Andione }\end{array}$ & An & DHTe & 3adiol & $\begin{array}{l}\text { Oestro- } \\
\text { gens }\end{array}$ & \\
\hline 1 & DHA & $3 \cdot 18$ & ND & ND & ND & ND & ND & ND & ND & $3 \cdot 18$ \\
\hline 5 & & $6 \cdot 60$ & ND & ND & ND & ND & ND & ND & ND & 6.60 \\
\hline 1 & Ad & ND & - & 0.87 & $27 \cdot 3$ & $3.91 \dagger$ & ND & ND & ND & $32 \cdot 1$ \\
\hline 9 & & ND & - & 1.33 & $36 \cdot 6$ & $14.6 \dagger$ & ND & ND & ND & 52.5 \\
\hline 1 & $\mathrm{Te}$ & ND & $3 \cdot 12$ & - & $1.44 \dagger$ & ND & 4.99 & $2.42 \dagger$ & ND & $12 \cdot 0$ \\
\hline 5 & & ND & 2.02 & - & $3.33 \dagger$ & $1.90 \dagger$ & $13 \cdot 0$ & $11.8 \dagger$ & ND & $32 \cdot 1$ \\
\hline
\end{tabular}

Values are the mean of two incubations. $\mathrm{ND}$, none detected; $\mathrm{DHA}=$ dehydroepiandrosterone; ${ }^{\mathbf{5}} \mathrm{A}=\mathbf{5}$-androstene-3 $\beta, 17 \beta$-diol $; \mathrm{Ad}=$ androstenedione $; \mathrm{Te}=$ testosterone $;$ EpiTe $=$ epitestosterone $; 5 \alpha$ Andione $=5 \alpha$-androstane3,17-dione; $\mathrm{An}=$ androsterone $; \mathrm{DHTe}=5 \alpha$-dihydrotestosterone; $3 \alpha$ diol $=5 \alpha$-androstane-3 $\alpha, 17 \beta$-diol.

* Initial incubation with $\left[{ }^{3} \mathrm{H}\right]$ androstenedione yielded testosterone $(0.26 \%)$ and epitestosterone $(0.57 \%)$ after paper chromatography Bush A (15 h).

$\uparrow$ Radioactivity coincident with authent ic steroid in several chromatography systems including radio-gas chromatography (Panex Ltd, Mitcham, Surrey; Pye-Unicam, Cambridge) for identifying $5 \alpha$-androstane-3 $\alpha, 17 \beta$-diol, but failure to recrystallize to a constant specific activity. Some of these conversion values are overestimates due to the presence of impurities (see Table 3).

Table 3. Recrystallization to constant specific activity of metabolites (c.p.m./mg) obtained from incubations of rabbit blastocysts (Day 6 p.c.) with ${ }^{3} \mathrm{H}$-labelled steroid substrates

\begin{tabular}{|c|c|c|c|c|}
\hline \multirow[b]{2}{*}{ Steroid isolated } & \multicolumn{3}{|c|}{ Crystallizations } & \multirow[b]{2}{*}{ Steroid substrate } \\
\hline & $I^{*}$ & $2 \dagger$ & $3 \ddagger$ & \\
\hline 5-Androstene- $3 \beta, 17 \beta$-diol & 2845 & 2761 & - & Dehydroepiandrosterone \\
\hline Testosterone & $89 \cdot 5$ & 106 & 109 & Androstenedione \\
\hline Epitestosterone & 255 & 342 & 259 & Androstenedione \\
\hline $5 \alpha$-Androstane-3,17-dione & 2797 & 815 & 615 & Androstenedione \\
\hline Androstenedione & 1427 & 1691 & 1757 & Testosterone \\
\hline $5 \alpha$-Dihydrotestosterone & 133 & $64 \cdot 2$ & $57 \cdot 4$ & Testosterone \\
\hline $5 \beta$-Pregnane- 3,20 -dione & 19180 & 27168 & 22811 & Progesterone \\
\hline $5 \beta$-Pregnan-3 $\alpha$-ol-20-one & 4969 & 6253 & 5369 & Progesterone \\
\hline
\end{tabular}

* Methanol:water.

$\dagger$ Ethyl acetate or ethyl acetate:methanol.

$\ddagger$ Acetone: water or methanol:water. 
Incubation with pregnenolone produced a low yield of one detectable metabolite which was tentatively identified as $17 \alpha$-hydroxypregnenolone. Progesterone was extensively metabolized to $5 \beta$-pregnane-3,20-dione and 5 $\beta$-pregnan-3 $\alpha$-ol-20-one (Table 1). A third metabolite of considerable yield, particularly in the incubation with 5 blastocysts, was not identified, but evidence from thinlayer chromatography suggested it was a progestagen. Androgens or oestrogens were not formed in detectable amounts. The incubation with DHA produced a single metabolite which was identified as 5 -androstene-3 $\beta, 17 \beta$-diol (Table 2). There was extensive metabolism of androstenedione to other androgens but not to oestrogens (Table 2). Some androstenedione was converted to testosterone and epitestosterone, but the major metabolites were the $5 \alpha$-reduced steroids, $5 \alpha$-androstane- 3,17 -dione and androsterone (tentatively identified). The major metabolism of testosterone was also to $5 \alpha-$ reduced products with retention of the $17 \beta$-hydroxy group, including $5 \alpha$-dihydrotestosterone and $5 \alpha$-androstane- $3 \alpha, 17 \beta$-diol; again there was no evidence for oestrogen formation. In the incubations with added cofactors, the number and yields of metabolites were similar to those obtained in incubations without added cofactors. In control tubes without blastocysts the substrates remained unchanged.

\section{Oestrogen in blastocysts}

In the initial study (Group 1) in which radioimmunoassay was carried out directly on an extract of 52 blastocysts, a value of $146.2 \mathrm{pg}$ total unconjugated oestrogen $(2 \cdot 81 \mathrm{pg} /$ blastocyst $)$ was obtained. However, after purification by thin-layer chromatography of the blastocyst extracts of Groups 2 and 3 (Text-figs $1 \mathrm{a}$ and $1 \mathrm{~b}$ ), correspondingly much higher values for both oestradiol and oestrone were found: Group 2, $37.3 \mathrm{ng}$ oestradiol $(86.8 \mathrm{pg} /$ blastocyst) and $20.8 \mathrm{ng}$ oestrone $(48.4 \mathrm{pg} /$ blastocyst); Group $3,2.49 \mathrm{ng}$ oestradiol ( $18.2 \mathrm{pg} /$ blastocyst $)$ and $880 \mathrm{pg}$ oestrone $(6.42 \mathrm{pg} /$ blastocyst $)$. Uterine flushings of Group 3 rabbits also contained material (Text-fig. 1c) which behaved in the radioimmunoassay like oestradiol, $4.7 \mathrm{ng}$ (132 pg/uterine horn), and oestrone, $6.21 \mathrm{ng}$ (173 pg/uterine horn). In all cases, linearity was maintained when different dilutions of each extract were assayed.
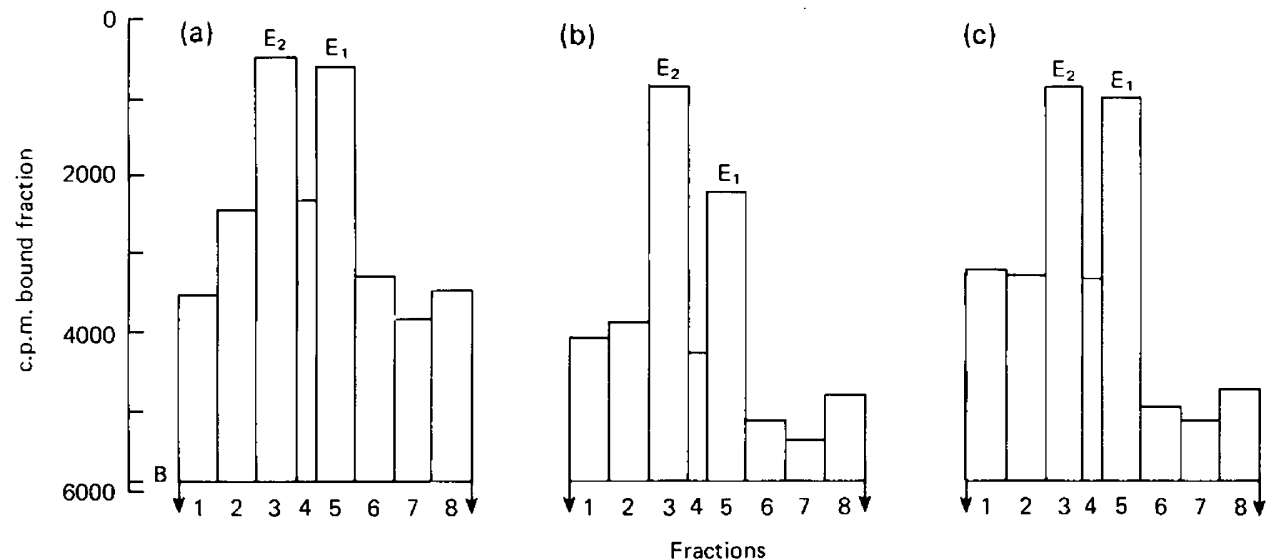

Text-fig. 1. Displacement of $\left[2,4,6,7(\mathrm{n}) \cdot{ }^{3} \mathrm{H}\right]$ oestradiol- $17 \beta$ from antiserum to oestradiol-17 $\beta$-succinylbovine serum albumin by ether extracts ( 1 total) of $(a, b)$ rabbit blastocysts and (c) uterine flushings (Day 6 p.c.) following fractionation by thin-layer chromatography, benzene: ethyl acetate $(3: 1 \mathrm{v} / \mathrm{v})$. $\mathrm{B}=\mathrm{value}$ for bilank for silica gel $\left(6 \mathrm{~cm}^{2}\right)$ and solvent $(5 \mathrm{ml})$. The positions of authentic oestrone $\left(E_{1}\right)$ and oestradiol $\left(E_{2}\right)$ are indicated. The origin is at the left. (a) 430 blastocysts from 30 rabbits in Group 2; (b) 137 blastocysts from 18 rabbits in Group 3; (c) flushings (36) from each uterine horn of 18 rabbits in Group 3.

\section{Transfer of ${ }^{3} \mathrm{H}$-labelled oestradiol to blastocysts}

The results are shown in Table 4. The injection of $\left[{ }^{3} \mathrm{H}\right]$ oestradiol into female rabbits resulted in a high concentration of radioactivity associated with oestradiol in the uterine horns. By $6 \mathrm{~h}$ after injection of the labelled oestradiol, radioactivity was also associated with oestrone. However, from 
$45 \mathrm{~min}$ to $24 \mathrm{~h}$ after injection of the labelled steroid, there was a continuous decrease in the level of radioactivity in the blood plasma, and in the radioactivity associated with oestradiol in the uterus. Some radioactivity corresponding to oestradiol rather than oestrone was found in the uterine flushings and blastocysts between $45 \mathrm{~min}$ and $6 \mathrm{~h}$ after injection of $\left[{ }^{3} \mathrm{H}\right]$ oestradiol, but by $24 \mathrm{~h}$ there was no radioactivity in these steroid fractions in either the uterine flushings or blastocysts.

Table 4. Radioactivity corresponding to unconjugated ${ }^{3} \mathrm{H}$-labelled oestrogens (oestrone, $\mathrm{E}_{1}$, and oestradiol, $\mathrm{E}_{2}$ ) in ether extracts of uteri, uterine fluid and preimplantation blastocysts after an injection of $50 \mu \mathrm{Ci}\left[6,7-{ }^{3} \mathrm{H}\right]$ oestradiol$17 \beta$ into the marginal ear vein of female rabbits

\begin{tabular}{|c|c|c|c|c|c|c|c|}
\hline \multirow[b]{2}{*}{$\begin{array}{c}\text { Rabbit } \\
\text { no. }\end{array}$} & \multirow[b]{2}{*}{$\begin{array}{c}\text { Day of } \\
\text { injection } \\
(\text { p.c. })\end{array}$} & \multirow[b]{2}{*}{$\begin{array}{l}\text { Interval } \\
\text { between injec- } \\
\text { tion and } \\
\text { autopsy }\end{array}$} & \multicolumn{5}{|c|}{ Radioactivity } \\
\hline & & & $\begin{array}{c}\text { Blood } \\
\text { plasma } \\
\text { (c.p.m./ml)* }\end{array}$ & Hormone & $\begin{array}{c}\text { Uteri } \\
\text { (c.p.m./organs) }\end{array}$ & $\begin{array}{l}\text { Uterine } \\
\text { flushings } \\
\text { (c.p.m.) }\end{array}$ & $\begin{array}{c}\text { Blastocysts }+ \\
\text { (c.p.m.) }\end{array}$ \\
\hline $27 / 1$ & 5 & $45 \mathrm{~min}$ & 1167 & $\begin{array}{l}E_{1} \\
E_{2}\end{array}$ & $\begin{array}{c}\text { ND } \\
400000\end{array}$ & $\begin{array}{l}\text { ND } \\
434\end{array}$ & $\mathrm{ND}_{69}(10)$ \\
\hline $37 / 6$ & 5 & $75 \mathrm{~min}$ & 1392 & $\begin{array}{l}E_{1} \\
E_{2}\end{array}$ & $\begin{array}{c}\text { ND } \\
282480\end{array}$ & $\begin{array}{l}\text { ND } \\
885\end{array}$ & ${ }_{1359}^{N D}(9)$ \\
\hline $1 / 3$ & 6 & $6 \mathrm{~h}$ & 196 & $\begin{array}{l}E_{1} \\
E_{2}\end{array}$ & $\begin{array}{r}11250 \\
143670\end{array}$ & $\begin{array}{l}102 \\
665\end{array}$ & $\mathrm{ND}_{175}(9)$ \\
\hline $48 / 2$ & 6 & $6 \mathrm{~h}$ & 238 & $\begin{array}{l}E_{1} \\
E_{2}\end{array}$ & $\begin{array}{r}8310 \\
147050\end{array}$ & $\begin{array}{r}\text { ND } \\
1319\end{array}$ & $\mathrm{ND}_{142}(8)$ \\
\hline $5 / 4$ & 5 & $24 \mathrm{~h}$ & $49 \ddagger$ & $\begin{array}{l}E_{1} \\
E_{2}\end{array}$ & $\begin{array}{l}\text { ND } \\
15180\end{array}$ & ND & ND (19) \\
\hline $6 / 4$ & 5 & $24 \mathrm{~h}$ & $48 \ddagger$ & $\begin{array}{l}E_{1} \\
E_{2}\end{array}$ & $\begin{array}{l}\text { ND } \\
14000\end{array}$ & ND & ND (13) \\
\hline $46 / 2$ & Oestrus & $6 \mathrm{~h}$ & 190 & $\begin{array}{l}E_{2} \\
E_{2}\end{array}$ & $\begin{array}{c}\text { ND } \\
125000\end{array}$ & $\begin{array}{l}\text { ND } \\
106\end{array}$ & - \\
\hline
\end{tabular}

$\mathrm{ND}=$ none detected. Rabbits $5 / 4$ and $6 / 4$ were induced to superovulate, the remaining rabbits were induced to give normal ovulations (see 'Materials and Methods').

* Total radioactivity in ether extracts of blood plasma.

$\dagger$ No. in parentheses.

$\ddagger$ Background, 40-45 c.p.m.

\section{Discussion}

The metabolism of radioactively labelled progesterone was similar to that found by Huff \& Eik-Nes (1966), although fewer metabolites were found in the present study. The progesterone metabolite we could not identify did not appear to be $20 \alpha$-dihydroprogesterone which was found by Huff \& EikNes (1966); it is possible that the metabolite was a $5 \beta$ progestagen further reduced at the $3(\alpha$ or $\beta$ )- or 20 ( $\alpha$ or $\beta$ )-ketone groups (Strott, 1975). Progesterone metabolism to other progestagens is either an integral part of progesterone activity or conversely inactivation of this steroid. Our findings indicate that the progesterone that occurs in high concentrations in the uterine fluid and blastocyst of the rabbit (Seamark \& Lutwak-Mann, 1972; Fuchs \& Beling, 1974; Cowan et al., 1976; Borland et al., 1977; Fowler et al., 1977) is readily metabolized to $5 \beta$ metabolites, rather than the $5 \alpha$ metabolites that are usually formed in tissues responding to progesterone (Martini, 1977). The blastocyst may thus reduce exposure of its cells to what might otherwise be toxic levels of the steroid. In support of this hypothesis, Maurer \& Beier (1976) have shown that progesterone added to rabbit blastocysts in culture retards embryonic development in vitro. Like Huff \& Eik-Nes (1966), we could find no evidence for the formation of androgen or oestrogen from progesterone, even when cofactors were added to the incubations. The possibility that our incubation system contained factors which might be inhibiting aromatase activity is unlikely because high yields of oestradiol-17 $\beta$ and oestrone were obtained when sheep ovarian follicles were incubated with $\left[{ }^{3} \mathrm{H}\right]$ androstenedione under the same conditions as those used for the rabbit blastocysts. 
We were unable to demonstrate any oestrogen formation from androgen substrates, but there was extensive metabolism of androgens to other $C_{19}$ steroids. The single product, 5 -androstene-3 $3,17 \beta$ diol, obtained in the incubations with DHA shows that $17 \beta$-hydroxysteroid dehydrogenase is present in Day- 6 rabbit blastocysts, a finding in keeping with the histochemical observations of Dickmann et al. (1975) who used oestradiol as a substrate. However, contrary to their histochemical evidence we failed to obtain any conversion of DHA to androstenedione or testosterone, which would have demonstrated the presence of $3 \beta$-hydroxy, 5-unsaturated steroid dehydrogenase. In the present study, androstenedione and testosterone were interconverted, again demonstrating the presence of $17 \beta$-hydroxysteroid dehydrogenase in rabbit blastocysts. Furthermore, $17 \alpha$-hydroxysteroid dehydrogenase is also present, as shown by the formation of epitestosterone from androstenedione. Of greater interest with regard to androgen metabolism was the formation of the $5 \alpha$-reduced steroids, $5 \alpha$-androstane-3,17-dione and androsterone (tentatively identified) from androstenedione, and $5 \alpha-$ dihydrotestosterone and $5 \alpha$-androstane-3 $3 \alpha, 17 \beta$-diol, both potent androgens, from testosterone. The fall in specific activity of the fractions corresponding to $5 \alpha$-androstane-3,17-dione and $5 \alpha$-dihydrotestosterone after the first recrystallization indicated the presence of impurities. Therefore the yields of these steroids, which were calculated before recrystallizations were carried out, are probably overestimated values. Although androgens have not been detected in blastocysts or uterine flushings of pregnant rabbits (Borland et al., 1977), the ability of rabbit blastocysts to metabolize androgens involving both $5 \alpha$-reductase and $3 \alpha$-hydroxysteroid dehydrogenase shows that they have a potential to metabolize steroids comparable to that in androgen target tissues (Wilson, 1975). This potential may not be utilized in vivo at this stage in embryonic development, but could be involved after implantation for growth and differentiation of the embryo.

The level of total unconjugated oestrogen determined by radioimmunoassay in a crude extract of Day-6- rabbit blastocysts (Group 1) is similar to that found by Dickmann et al. (1975) and Borland et al. (1977). The relatively much higher levels of oestrogen found after fractionation into oestradiol and oestrone in blastocysts of rabbits (Groups 2 and 3 ) is difficult to explain, and may be related to superovulation. Superovulation in cattle leads to considerably elevated levels of oestrogen and progesterone in maternal blood plasma, particularly at Day 6 (Booth et al., 1975); whether this occurs in the superovulating rabbit is unknown. Oestradiol and oestrone were present in the rabbit blastocysts and uterine flushings, but little significance can be attached to the relative amounts of these two steroids because extraction losses were not determined. Although high oestrogen levels were found in the blastocysts of superovulating rabbits, the levels in the uterine flushings of these rabbits are comparable to those found by Borland et al. (1977), although unlike us Borland et al. did not find oestrone in either blastocysts or uterine flushings.

In rabbits injected with ${ }^{3} \mathrm{H}$-labelled oestradiol, radioactivity associated with oestradiol had accumulated in the uterine horns very rapidly, by $45 \mathrm{~min}$ after injection of the steroid, and some radioactivity was present in the horns $24 \mathrm{~h}$ later, whereas radioactivity in ether extracts of blood plasma had fallen to background levels by $24 \mathrm{~h}$; these findings are in keeping with the fact that oestrogen is readily bound to receptors in the uterus (Gorski, Toft, Shyamala, Smith \& Notides, 1968). The presence of labelled oestrone in the uterus $6 \mathrm{~h}$ after the injection of labelled oestradiol indicated that significant oxidation of oestradiol to oestrone in the uterus, or elsewhere, occurs some time after the initial uptake of oestradiol. Radioactivity associated with oestrogen was found in the uterine flushings and blastocysts at the same time as the maximum accumulation of radioactive oestrogen in the uterine tissue. The possibility that the flushings and blastocysts may have been contaminated with radioactive oestrogen arising from cells sloughed from the endometrium is unlikely as the flushings were centrifuged to precipitate cells and the blastocysts were washed several times with phosphate-buffered saline. Furthermore, even if the endometrial cells collapsed during centrifugation, the amount of radioactivity that was present in several $\mathrm{mg}$ of endometrium $6 \mathrm{~h}$ after the injection of labelled oestradiol was probably no more than 2500 c.p.m. (assuming 10 -fold the amount at $24 \mathrm{~h}$ ), which is low in relation to the number of counts found in the flushings and blastocysts with, proportionally, considerably lower tissue masses.

In conclusion, our work has demonstrated that Day- 6 rabbit blastocysts have the capacity to metabolize androgens in vitro in a manner which is typical of androgen target tissues; the significance 
of this metabolism to the blastocysts in vivo remains to be determined. We have also confirmed that rabbit blastocysts have the capacity to convert progesterone to less active progestagens. This metabolic potential appears to be very efficient, and so only minimal amounts of progesterone may be available to the blastocysts as a substrate for steroid syntheses. Our failure to obtain androgen and oestrogen in our incubations with progesterone is in keeping with this suggestion. Whether or not the preimplantation rabbit blastocyst produces significant amounts of oestrogen in vivo, our work indicates that oestrogen in the blastocyst may be partly of maternal origin, as suggested by Borland et al. (1977). Further work is required to establish the relative importance of maternal oestrogen (Hilliard \& Eaton, 1971), oestrogen of embryonic origin (Dey, Dickmann \& Sen Gupta, 1976), or both, in relation to implantation and other stages of pregnancy critical to the survival of the rabbit conceptus.

We thank Dr C. E. Adams for his interest in the work and reading the manuscript; $\mathrm{Mr} \mathrm{M}$. L. Norris for assistance with superovulation procedures; Mr D. Green and Miss J. S. Hilton for their help with the radioimmunoassay of oestrogens; Dr R. M. Moor for supplying the sheep ovarian follicles; Dr B. J. A. Furr (I.C.I. Ltd, Mereside, Alderley Park, Macclesfield, Cheshire, U.K.) for the gift of antiserum for radioimmunoassay; and Dr R. B. Heap and Mr J. E. Gadsby for their useful criticism of the manuscript. This investigation received financial support from the World Health Organization.

\section{References}

BooTH, W.D. (1977) Metabolism of androgens in vitro by the submaxillary salivary gland of the mature domestic boar. J. Endocr. 75, 145-154.

Booth, W.D., Newcomb, R., Strange, H., Rowson, L.E.A. \& SACHER, H.B. (1975) Plasma oestrogen and progesterone in relation to superovulation and egg recovery in the cow. Vet. Rec. 97, 366-369.

Borland, R.M., Erickson, G.F. \& Ducibella, T. (1977) Accumulation of steroids in rabbit preimplantation blastocysts. J. Reprod. Fert. 49, 219224.

Cowan, B.D., Manes, C. \& Hagerman, D.D. (1976) Progesterone concentration in rabbit uterine flushings before implantation. $J$. Reprod. Fert. 47, 359361.

Dey, S.K., DickmanN, Z. \& Sen Gupta, J.S. (1976) Evidence that the maintenance of early pregnancy in the rabbit requires "blastocyst oestrogen". Steroids 28, $481-485$.

Dickmann, Z., Dey, S.K. \& Sen Gupta, J.S. (1975) Steroidogenesis in rabbit preimplantation embryos. Proc. natn. Acad. Sci. U.S.A. 72, 298-300.

Fowler, R.E., JohnSon, M.H., Walters, D.E. \& EAGER, D.D. (1977) The progesterone content of rabbit uterine flushings. $J$. Reprod. Fert. 50, 301-308.

Fuchs, A.R. \& Beling, C. (1974) Evidence for early ovarian recognition of blastocysts in rabbits. Endocrinology 95, 1054-1058.

Gadsby, J.E., Burton, R.D., Heap, R.B. \& Perry, J.S. (1976) Steroid metabolism and synthesis in early embryonic tissue of pig, sheep and cow. J. Endocr. $71,45 P-46 P$.

Gorski, J., Toft, D., Shyamala, G., Smith, D. \& Notides, A. (1968) Hormone receptors: studies on the interaction of oestrogen with the uterus. Recent Prog. Horm. Res. 24, 45-80.
GOWER, D.B. (1964) Chromatographic separation of $\mathrm{C}_{19}$-16-dehydrosteroids. J. Chromat. 14, 424-431.

Hilliard, J. \& Eaton, L.W. (1971) Estradiol-17ß, progesterone and $20 \alpha$-hydroxypregn-4-en-3-one in rabbit ovarian plasma. II. From mating through implantation. Endocrinology 89, 522-527.

HufF, R.L. \& EIK-Nes, K.B. (1966) Metabolism in vitro of acetate and certain steroids by six-day-old rabbit blastocysts. J. Reprod. Fert. 11, 57-63.

MarTini, L. (1977) Recent views on the control of anterior pituitary function. Acta endocr., Copenh., Suppl. 214, 19-32.

Maurer, R.R. \& Beier, H.M. (1976) Uterine proteins and development in vitro of rabbit preimplantation embryos. J. Reprod. Fert. 48, 33-41.

Newcomb, R., Booth, W.D. \& Rowson, L.E.A. (1977) The effect of oxytocin treatment on the levels of prostaglandin $\mathrm{F}$ in the blood of heifers. J. Reprod. Fert. 49, 17-24.

Perry, J.S., Heap, R.B. \& Amoroso, E.C. (1973) Steroid hormone production by pig blastocysts. Nature, Lond. 245, 45-47.

Seamark, R.F. \& Lutwak-Mann, C. (1972) Progestin in rabbit blastocysts. J. Reprod. Fert. 29, 147-148.

Strott, C. (1975) Isolation of progesterone metabolites. In Methods in Enzymology, Vol. 36, Hormone Action, Part A, Steroid Hormones, pp. 489 498. Eds B. W. O'Malley \& J. G. Hardman. Academic Press, New York.

WILSON, J.D. (1975) Metabolism of testicular androgens. In Handbook of Physiology, Vol. 5, pp. 491-508. Eds D. W. Hamilton \& R. O. Greep. Am. Physiol. Soc., Williams \& Wilkins, Baltimore.

Received 25 October 1977 